\title{
Cereal Cultivation and Nomad-Sedentary Interactions at the Late Bronze Age Settlement of Zawiyet Umm el- Rakham
}

\section{DOI:}

10.15184/aqy.2017.174

\section{Document Version}

Accepted author manuscript

Link to publication record in Manchester Research Explorer

Citation for published version (APA):

Nielsen, N. (2017). Cereal Cultivation and Nomad-Sedentary Interactions at the Late Bronze Age Settlement of Zawiyet Umm el-Rakham. Antiquity, 91(360), 1561. https://doi.org/10.15184/aqy.2017.174

\section{Published in:}

Antiquity

\section{Citing this paper}

Please note that where the full-text provided on Manchester Research Explorer is the Author Accepted Manuscript or Proof version this may differ from the final Published version. If citing, it is advised that you check and use the publisher's definitive version.

\section{General rights}

Copyright and moral rights for the publications made accessible in the Research Explorer are retained by the authors and/or other copyright owners and it is a condition of accessing publications that users recognise and abide by the legal requirements associated with these rights.

\section{Takedown policy}

If you believe that this document breaches copyright please refer to the University of Manchester's Takedown Procedures [http://man.ac.uk/04Y6Bo] or contact uml.scholarlycommunications@manchester.ac.uk providing relevant details, so we can investigate your claim.

\section{OPEN ACCESS}




\section{[For Research section]}

\section{Cereal cultivation and nomad-sedentary interactions at the Late Bronze Age settlement of Zawiyet Umm el-Rakham}

Nicky Nielsen*

*University of Manchester, 1.202B Stopford Building, M13 9PT Manchester, UK (Email: nicky.nielsen@manchester.ac.uk)

Received: 1 September 2016; Accepted: 18 December 2017; Revised: 30 January 2017

<LOCATION MAP, $6.5 \mathrm{~cm}$ colour, place to left of abstract and wrap text around> Research on Late Bronze Age relations between Egyptians and local nomadic or seminomadic Libyans has hitherto focused almost exclusively on Egyptian textual and iconographic sources. Recent archaeological evidence for grain production and agrarian practice at the Egyptian fortress of Zawiyet Umm el-Rakham allows us to address this imbalance, in combination with ethnographic data and cross-cultural parallels drawn from nomad-sedentary interactions in the Near East. Results suggest that Egyptian subsistence in this relatively isolated outpost of the New Kingdom Empire was probably dependent upon Libyan manpower and their knowledge of local environmental conditions and effective farming methods.

Keywords: Egypt, Libya, Bronze Age, nomadism, sedentism, cultivation

\section{Introduction}

Modern investigation of relations between the Late Bronze Age Pharaonic state and the pastoralists who inhabited the Western Desert (commonly referred to as 'Libyans'; Snape 2003) has suffered from a near absence of archaeological and textual material produced by the semi-nomadic societies themselves. This, in turn, has prompted scholars to rely on Egyptian textual and iconographic sources to inform about Libyan culture and Egypto-Libyan relations. This enforced focus initially resulted in scholarly dismissals of Late Bronze Age Libyans as culturally inferior to their Egyptian neighbours (Bates 1914; Holscher 1955). Later researchers attempted to reconstruct Libyan society and political divisions on the shaky foundation of subjective source material, such as depictions of Libyans in Egyptian royal and private monumental architecture (O’Connor 1990 contra Ritner 2009). Attempts to identify 
settlements of Late Bronze Age Libyans in the archaeological record have been inconclusive, aside from limited evidence of occupation from Bates' Island and Zawiyet Umm el-Rakham. The latter is an Egyptian fortress located 320km west of Alexandria (Carter 1963; Hounsell 2002; Simpson 2002; White 2002).

Founded during the reign of Ramesses II and occupied for only a brief period of around fifty years, the fortress of Zawiyet Umm el-Rakham (Figures 1-2) has been explored by successive missions, initially led by Alan Rowe in 1946, by Labib Habachi in 1949 and from 1953-1955, and since 1994 by a University of Liverpool mission under the direction of Steven Snape (Rowe 1953, 1954; Leclant 1954, 1955, 1956; Habachi 1980; Snape 1998, 2003, 2004, 2010, 2013; Snape \& Wilson 2007).

$<$ FIGURE $1,13.5 \mathrm{~cm}$ colour>

$<$ FIGURE 2, $13.5 \mathrm{~cm}$ colour $>$

The fortress was surrounded by a mud-brick enclosure wall and housed a temple and a series of private chapels, as well as domestic areas ( $\mathrm{K}$ and $\mathrm{N})$, storage magazines and granaries (Simpson 2002; Snape \& Wilson 2007). Simpson (2002) suggests that substantial quantities of ostrich eggs were bartered by local tribes to the Egyptian occupants, possibly in exchange for metal objects, a topic also examined by Hulin (2011) in relation to evidence of Late Bronze Age metallurgy on Bate's Island. Recent research has focused on the archaeological material found in the site's provisioning zone, area K (Figure 3; Snape 2010; Nielsen 2016a \& b; Gasperini 2017), including a large assemblage of objects related to the procurement and processing of cereal products. The investigation of this material - in conjunction with textual data from the site-presents a unique source of further information concerning interactions between this sedentary Egyptian enclave and nearby Libyan nomads during the brief occupation of the fort. Complementing this evidence are cross-cultural data concerning nomad-sedentary relations in the Near East and North Africa.

$<$ FIGURE $3,13.5 \mathrm{~cm}$ colour>

\section{Cereal cultivation and processing at Zawiyet Umm el-Rakham}

Herodotus claimed that the "eastern region of Libya, where the nomads live is low-lying, sandy flat land up to the Triton River" (Herodotus 4.191, Strassler 2009: 359), and, therefore, that the nomadic occupants of Eastern Libya were sustained entirely by milk and the flesh of their animals (Herodotus IV: 186, Strassler 2009: 358). This claim has, in recent years, been challenged by a number of surveys of the eastern Marmarica region between Mersa Matrouh and Zawiyet Umm el-Rakham (White 1999: 932; Hulin, 2001: 74; Vetter et al. 2009; Rieger 
et al. 2012; Vetter et al. 2013; Vetter et al. 2014). These surveys have helped to create a more nuanced picture of the agricultural potential of the coastal zone and the many wadis that bisect the area. Papyrus Vatican II from the Marmarica region, which dates to the second century $\mathrm{AD}$, lists barley as the predominant cereal, alongside smaller amounts of wheat and beans, vines, olives, figs and dates grown in the area (Johnson 1959: 58-62). Several of these crops, such as barley, olives and figs, remain local staples today (Figure 4). Complementing this textual evidence are a series of Ptolemaic settlements identified in the area south of Zawiyet Umm el-Rakham at Wadi Umm el-Ashdan, Wadi Qasaba and Wadi Magid, as well as a widespread network of cisterns, embanked fields and other evidence of 'water harvesting' dating mostly to Classical antiquity, spread throughout the surveyed area (Rieger et al. 2012: 166-68; Vetter et al. 2013: fig. 13; Vetter et al. 2014: 50-53).

$<$ FIGURE 4, $13.5 \mathrm{~cm}$ colour>

A group of these water-harvesting structures discovered at Wadi Magid, located 8km southeast of Zawiyet Umm el-Rakham, were dated using optically stimulated luminescence to between 1193 and 1153 BC, making them broadly contemporaneous with the Egyptian occupation at Zawiyet Umm el-Rakham (Rhodes 2011; Rieger et al. 2012: 167). Similar dating methods used at embanked fields in Wadi Umm el-Ashdan, located $2 \mathrm{~km}$ south of Zawiyet Umm el-Rakham, provided dates ranging from the First Intermediate Period (21812055 BC) through to the Ptolemaic Period (305-30 BC) (Rieger et al. 2012: 167). Ceramic surveys conducted by Linda Hulin (2001: 68) revealed concentrations of Egyptian and Egyptian-style Ramesside pottery in the wadis south of Zawiyet Umm el-Rakham, close to the areas discussed above. The presence of Egyptian material and Late Bronze Age waterharvesting structures south of the fortress suggests that the Egyptian occupants of Zawiyet Umm el-Rakham exploited these fertile zones for agricultural purposes. What is less clear is how Egyptians from the Nile Valley, with an inundation-based agricultural system, acquired the technological expertise and local knowledge of hydrological conditions to irrigate the soil effectively (Rieger et al. 2012: 168).

From the OSL dates provided by Rieger et al. (2012: 167-68), it is clear that farming in this area pre-dates the Egyptian occupation by several hundred years, from at least the Middle Kingdom onwards. Ethnographic evidence from the Cyrenaica region of Libya highlights the importance of seasonal agriculture conducted by nomadic tribes, a practice that was also described in detail by pre-industrial travellers to the region (Lyon 1821: 44; Behnke 1980: 40-48; Cribb 1991). Similar opportunistic agriculture was probably conducted by the Marmarican nomads during Pharaonic times as a means of supplementing a diet based around 
herd animals. Such agricultural pursuits would have required knowledge of the hydrological conditions in the eastern Marmarica region; it is therefore possible that the Egyptian occupants at Zawiyet Umm el-Rakham relied on information and aid from local nomads familiar with this type of agriculture to farm the wadis to the south of the fort effectively. It is in this context that the following passage from the biography of Nebre, the commander of Zawiyet Umm el-Rakham, should be viewed:

He made [the Libyans] masters/possessors of settlements, so that they would plant trees; so that they would work many vineyards and [///] in the countryside (Snape \& Godenho in press).

The primary archaeological evidence from Zawiyet Umm el-Rakham for the harvesting of cereal products consists of assemblages of flint sickle blades (Figure 5) found in area K, along with a far larger quantity in the magazines located north of the fort's temple (Simpson, 2002: 326-27). Storage facilities in the form of three circular granaries (area $\mathrm{H}$ ) built immediately adjacent to area K were excavated at the site in 2001 (Simpson 2002). Tools for processing cereal products into flour are among the most common small finds recorded from area K, with 36 saddle querns made from the local biosparite limestone, and 22 hand stones made from either local limestone or, more commonly, from imported hard stones, such as quartzite and granite. Fifteen domed bread ovens of similar form and size to New Kingdom examples from Deir el-Medina, the Workman's Village at Tell el-Amarna, and Amara West were also excavated in area K (Bruyère 1937-1939: 72-74; Samuel 1999, 2000: 566; Spencer 2015). Only six were found complete, while the remainder showed signs of deliberate removal, probably as the structural layout of the area was changed (Nielsen 2016b: 55-91). $<$ FIGURE 5, 6.5cm colour>

Several factors would have determined the extent of land required for cultivation to feed the occupants at Zawiyet Umm el-Rakham: population size, calorific requirements and yields for barley and emmer wheat. Using inscriptional evidence found at the site, Snape and Wilson (2007: 128) proposed a population of 500 people. An alternative methodology for calculating population size is the dwelling-based estimate championed by Zorn (1994). With eight excavated dwellings in areas $\mathrm{N}$ and $\mathrm{K}$ (representing 16 per cent of the fortified enclosure), and an estimated five occupants on average per dwelling (Zorn 1994: 33), a population of approximately 230 is suggested. This is similar to the number of occupants estimated for the Ramesside fort at Amara West (Spencer 2014: 4). While cereal crops were crucial to the ancient Egyptian diet, other plants (pulses and legumes, for example) provided a portion of 
daily calorific requirements, as did protein from meat and dairy. On the basis of archaeobotanical and ethnographic data, Padgham (2014: 21) estimates that cereals (emmer wheat and barley) provided 72.7 per cent of the annual calorific intake of New Kingdom Egyptians, with 55.6 per cent coming from barley bread and barley beer, and 17.1 per cent from emmer bread. With an estimated population of 230, Zawiyet Umm el-Rakham would require $230 \mathrm{~kg} / \mathrm{yr}$ of barley and $56 \mathrm{~kg} / \mathrm{yr}$ of emmer wheat per person. When an additional 10 per cent of the harvest for seed corn and 15 per cent covering loss and wastage are included, this provides a total annual requirement of $66125 \mathrm{~kg} / \mathrm{yr}$ of barley and $16100 \mathrm{~kg} / \mathrm{yr}$ of emmer wheat to supply the occupants at Zawiyet Umm el-Rakham.

Using an extensive ground and satellite survey of a $30 \mathrm{~km}$ east-west by $15 \mathrm{~km}$ north-south area of land south of Mersa Matrouh, Vetter et al. (2009: 20) concluded that roughly 9 per cent $\left(40.5 \mathrm{~km}^{2}\right)$ of this area consisted of potentially arable land. At most, that would provide 4050ha of suitable land in the area surrounding Zawiyet Umm el-Rakham. Vetter et al. (2009: 20) proposed that assuming a barley yield of 1T/ha, this area could potentially feed 22 000 people. Ethnographic data from similar environments in the Levant, however, suggest that a lower yield averaging 646.7kg/ha is a more realistic figure (Padgham 2014: 132). According to Papyrus Vatican II, the area during the second century AD averaged $570 \mathrm{~kg} / \mathrm{ha}$ for barley and 521kg/ha for emmer wheat (Applebaum 1979: 99-100). Using these lower yield rates, the occupants at Zawiyet Umm el-Rakham would have needed to cultivate 147 ha (or 3.63 per cent) of the immediately available arable land to maintain the required supply of cereal products for 230 inhabitants. Any additional grain produced as payment for Libyan assistance in the agricultural process should also be considered. The size of such a Libyan community is impossible to determine with any accuracy, given the dearth of archaeological data concerning Late Bronze Age Libyan communities. Assuming a population approximately equal to that of the Egyptian occupants at Zawiyet Umm el-Rakham, however, the amount of cultivated land required rises to $294 \mathrm{ha}$ (or 7.26 per cent) of the immediately available arable land. This number is broadly comparable to the land required (320ha/7.89 per cent) to sustain the highest estimated population number of 500 (Snape \& Wilson 2007: 128).

Even considering the probability that some of the grain consumed at the site was shipped from Egypt (Snape 2013), the archaeological evidence from Wadi Magid and Zawiyet Umm el-Rakham combine to show extensive and well-developed cereal cultivation and processing that was capable of sustaining the settlement and mitigating against delays or missing deliveries from Egypt. The knowledge of local climatic conditions and the hydrological 
constructions involved in the 'water harvesting' required for any local agriculture is, however, unlikely to have come from the Egyptian occupants at the site. Rather, the local semi-nomadic communities probably assisted the Egyptian population with creating and maintaining their agricultural regime.

\section{Nomad-sedentary interactions in Marmarica: cross-cultural perspective}

Building on the work of Michael Rowton (1973), modern scholars have recognised that 'nomadic' cultures did not exist insulated from sedentary groups, but chose from a spectrum of more or less sedentary strategies, engaging in agriculture, trade and various crafts, when required to supplement their basic pastoral economy (Szuchman 2009: 3, see too Finkelstein 1995: 37-38). Nomad-sedentary interaction between Egypt and its eastern and southern neighbours has been explored extensively, whereas the interaction between Egyptians and Libyans has been studied primarily on a macro-political level, using Egyptian textual and iconographic source material (Ritner 2009; cf Spalinger 1979; Osing 1980; Kitchen 1990; O’Connor 1990). Informal economic relations between communities of Libyans and sedentary Egyptians living in the Western Nile Delta and the Kharga oasis have also only recently been examined (García 2014).

By contrast, pastoral nomadism and its interaction with sedentary communities from various periods has been extensively investigated across the Levant (cf Cribb 1991; Haiman 1992; Rosen 2009). The categorisation of nomad-sedentary relations in Mesopotamia offers a particularly useful case study (Lönnqvist 2010). Juxtaposing textual and archaeological data obtained from excavations in the area of Jebel Bishri, Lönnqvist (2010: 132-33) identified nine models by which the Mesopotamian states either interacted with, or attempted to control the nomadic Amorites, known as MAR.TU in the Sumerian record, living on the boundaries of their territory. These models could be broadly hostile (e.g. constructing fortifications against nomadic communities or launching punitive military expeditions against them; using propaganda or magico-religious methods to control or attack desert environments and their occupants; and forced sedentism), or peaceful (e.g. establishing trade and alliances with nomadic communities; using nomads for labour or auxiliary troops; and engaging in reciprocal diplomatic gift giving).

A study of the source material that details Egyptian interactions with Libyan communities throughout the Pharaonic period suggests that similar methods were employed. The most obviously hostile modes deployed by sedentary communities, such as military aggression, are repeatedly evidenced in the Egyptian source material from the Middle Kingdom by 
Mentuhotep IV and Senwosret I, in the New Kingdom by Amenhotep III (Urk. IV, 1656, Sethe 1961: 1656), and crucially, in the Libyan Campaign of Seti I, conducted shortly before the construction of Zawiyet Umm el-Rakham (Sethe 1929: 3-17; Habachi 1963: 21-23 and pl. 5; Oriental Institute Epigraphic Survey 1986; KRI I 20: 15-24:5; Kitchen 1993: 15-24). The portrayal of nomadic societies as embodiments of chaos is similarly evidenced in Middle Kingdom literature, such as the Prophecies of Neferty and the Dialogue of Ipuwer and the Lord of All (Helck 1970: 55; Enmarch 2008: 238). The use of magic to control or hurt nomadic communities was also employed during the Middle Kingdom in the form of the Execration Texts, although the inclusion of the Libyans on this list is probably symbolic (Posener 1940: 25; Ritner 2009). More-peaceful interactions were also used by the Egyptian state, such as trade and alliance-building and the inclusion of Tjehenu Libyans as an auxiliary military force during both the Old and New Kingdoms (Urk. I, 98-110; Sethe 1933: 98-110; Urk. IV, 373; Sethe 1961: 373; KRI IV, 18:5-18:9;Kitchen 2003: 18; Davies 1905: pl. XXXI; Sagrillo 2012: 441).

The issue of sedentarising nomadic communities, either forcibly or by creating economic incentives, is obliquely referenced during the reign of Ramesses II, specifically on an inscribed block from Suez, on which it is claimed that Ramesses pursued a policy of: "[Resettling the] Libyans in settlements bearing his name, Lord of Crowns, Ramesses II" (KRI II, 406: 3). Another Ramessidetext further describes how the king "settled the Libyans (Tjehenu) on the ridges" (KRI II, 206: 18; Kitchen 1996: 206). The previously mentioned biography of Nebre, the commander of the fort at Zawiyet Umm el-Rakham, can be added to this data. Nebre describes the fortress as: "The Town of Ramesses II [...] which he built for these Libyan people, who had been living on the desert like jackals" (Snape \& Godenho in press).

While states have attempted forcibly to settle nomadic communities throughout history, a more peaceful sedentarisation through the creation of economic incentives is similarly wellattested, including in modern times. An example of this is the Egyptian governmental investments in infrastructure and agricultural projects in the Matrouh region in the 1950s and 1960s, which sought to encourage the local Bedouin to shift their economic focus from herding to agriculture (Abou-Zeid 1959). Writing during this period, Mohamed Awad (1954) noted the differentiation of nomadism among the communities in the Matrouh governorate. Certain groups led an almost entirely nomadic existence, travelling with their herds between the Western oases and the fertile coastal strip, while partially nomadic groupings lived more permanently along the coastal strip, exploiting it for the cultivation of cereal crops, olives and 
figs. Awad (1954: 249) notes that many of the wholly nomadic communities maintained kinship bonds with more sedentary populations living on agricultural land, whom they visited in order to sell goods and services (such as aid with the harvest) in exchange for agricultural products. Until recent times, a similar relationship existed between nomadic communities and the sedentary population of the Siwa Oasis (Cole \& Altorki 1998: 143).

Archaeologists working at Zawiyet Umm el-Rakham observe a similar economic mechanism regarding the excavation of the site. Local Bedouin, who live on a permanent or semipermanent basis along the fertile coastal strip where they engage in agriculture, have generally been employed as workmen by the Liverpool mission. If a larger workforce is required, they contact their more mobile kinsmen travelling with their herds, who come to the site to work for the duration of the excavation. Hence, the excavation offers a seasonal economic opportunity, not dissimilar to participation in the cultivation or harvesting of agricultural produce.

\section{Conclusion}

The evidence discussed above demonstrates the degree to which the Egyptian occupants of Zawiyet Umm el-Rakham relied on local agricultural production. This production, by extension, caused a reliance on local Libyan groupings not just for trade, but also for their knowledge of the local environment and effective farming methods. The participation of some of these local Libyans in the agricultural process itself is further suggested by the biography of Nebre. This interpretation also supports the more active role of Libyan pastoralists in their relations both with Egyptians and the Aegeans on Bates' Island, with regard to metallurgy (proposed by Hulin 2011).

Encouraging the nomadic communities to rely on sedentary products may have been part of a deliberate policy of 'soft' sedentarisation - thereby creating a situation wherein the Libyan nomads were partially or wholly reliant on agricultural produce controlled by the Egyptian occupants at Zawiyet Umm el-Rakham. An integrated buffer zone against other hostile groupings living farther west, such as the Meshwesh and Libu, could equally be created as a result (Snape 2003). Another consideration may have been the need to foster and maintain local, mutually beneficial alliances to guarantee the survival of the relatively isolated settlement. Zawiyet Umm el-Rakham evidently served multiple functions. Being heavily fortified and prominently built on a wide coastal plain, it served to demonstrate the power of the Egyptian state. The prevalence of Mycenaean and Levantine imports suggests that it also served as a possible harbour for passing merchant ships (Snape 1998). The settlement should 
too, however, be viewed as an economic attractor, which incentivised a more sedentary andfrom the point of view of the Egyptian occupants - controlled the lifestyle of the Libyan pastoralists.

This policy of interaction and mutual cooperation with local communities is again evident at New Kingdom forts in Nubia, such as Amara West (Spencer 2014). External factors, such as a possible environmental disaster causing a mass-migration of Libyans towards the Nile Valley during the reign of Merenptah (1213-1203 BC), the appearance of the Sea People and the general collapse of the Late Bronze Age international network, naturally affected the successful implementation of this policy and resulted in the abandonment of Zawiyet Umm el-Rakham, most probably around 1208 BC during the early reign of Merenptah.

\section{Acknowledgements}

The author would like to thank Steven Snape for advice and guidance. This article is based on research conducted at the University of Liverpool, which was funded by the Arts and Humanities Research Council.

\section{References}

ABOU-ZEID, A.M. 1959. The sedentarization of Nomads in the Western Desert of Egypt. International Social Science Journal 11: 550-53.

ApPlebaum, S. 1979. Jews and Greeks in ancient Cyrene. Leiden: E.J. Brill.

AwAD, M. 1954. The assimilation of Nomads in Egypt. Geographical Review 44: 240-52. https://doi.org/10.2307/212358

BATES, O. 1914. The eastern Libyans. London: MacMillan \& Co.

BEHNKE, R.H. 1980. The herders of Cyrenaica. Urbana: University of Illinois Press.

BRUYÈRE, B. 1937-1939. Rapport sur les fouilles de Deir el Medineh, 1933-34, 1934-35.

Cairo: Imprimerie de l'Institut Francais d'Archeologie Orientale.

CARTER, T.H. 1963. Reconnaissance in Cyrenaica. Expedition 5(4): 18-27.

Cole, D.P. \& S. AltorKI. 1998. Bedouin, settlers and holiday-makers: Egypt's changing northwest coast. Cairo: American University of Cairo Press.

CRIBB, R. 1991. Nomads in archaeology. Cambridge: Cambridge University Press. https://doi.org/10.1017/CBO9780511552205

DAVIES, N. DE. G. 1905. The rock tombs of El-Amarna: part III-the tombs of Huya and Ahmes. London: Egypt Exploration Society. 
ENMARCH, R. 2008. A world upturned: commentary on and analysis of the dialogue of Ipuwer and the Lord of All. London: Oxford University Press.

FINKELSTEIN, I. 1995. Living on the fringe: the archaeology and history of the Negev, Sinai and neighbouring regions in the Bronze and Iron Ages. Sheffield: Sheffield Academic.

GARCÍA, J.C.M. 2014. Invaders or just herders? Libyans in Egypt in the third and second millennia BCE. World Archaeology 46: 610-23.

GASPERINI, V. 2017. Goods from the wine-dark sea: typology of imports excavated at Zawiyet Umm el-Rakham in H. Franzmeier (ed.) Mit archäologischen Schichten Geschichte schreiben. Festschrift für Edgar B. Pusch zum 70. Geburtstag: 119-36. Hildesheim: Gerstenberg.

HABACHI, L. 1963. King Benhepetre Mentuhotep: his monuments, place in history, deification and unusual representations in the form of gods. MDAIK 19: 16-52. - 1980. The military posts of Ramesses II on the coastal road and the western part of the Delta. BIFAO 80: 13-30.

HaIMAN, M. 1992. Sedentism and pastoralism in the Negev highlands in the Early Bronze Age: results of the Western Negev highlands emergency survey, in O. Bar-Yosef \& A.M. Khazanov (ed.) Pastoralism in the Levant: archaeological materials in anthropological perspective: 93-104. Madison (WI): Prehistory.

Helck, W. 1970. Die Prophezeieung des Nfr-tj. Wiesbaden: Otto Harrassowitz. HOLSCHER, W. 1955. Libyer und Agypter: Beitrage zur Ethnologie und Geschichte Libyscher Volkerschaften nach den Altagyptischen Quellen. Hamburg \& New York: J.J. Augustin, Gluckstadt.

HounselL, D.D.U. 2002. The occupation of Marmarica in the Late Bronze Age: an archaeological and ethnographical study. Unpublished $\mathrm{PhD}$ dissertation, University of Liverpool.

Hulin, L. 2001. Marmaric wares: New Kingdom and later examples. LibStud 32: 67-78. https://doi.org/10.1017/s0263718900005756

- 2011. Pragmatic technology: issues in the interpretation of Libyan material culture, in K. Duistermaat \& I. Regulski (ed.) Intercultural contacts in the ancient Mediterranean: Proceedings of the International Conference at the Netherlands-Flemish Institute in Cairo, $25^{\text {th }}-29^{\text {th }}$ October 2008: 101-14. Leuven: Peeters.

JoHnson, A.C. 1959. Roman Egypt: to the reign of Diocletian. Paterson: Pageant. 
Kitchen, K.A. 1990. The arrival of the Libyans in Late New Kingdom Egypt, in A. Leahy (ed.) Libya and Egypt: 1300-750 BC: 15-27. London: University of London, Centre of Near and Middle Eastern Studies.

- 1993. Ramesside inscriptions, translated \& annotated: translations, volume I. Ramesses I, Sethos I and contemporaries. Oxford: Blackwell.

- 1996. Ramesside inscriptions, translated \& annotated: translations, volume II. Ramesses II, royal inscriptions. Oxford: Blackwell.

- 2003. Ramesside inscriptions, translated \& annotated: translations, volume IV. Merenptah and the late Nineteenth Dynasty. Oxford: Blackwell.

LECLANT, J. 1954. Fouilles et Travaux en Égypte 1952-1953. Orientalia 23: 64-79.

- 1955. Fouilles et Travaux en Égypte 1953-1954. Orientalia 24: 296-317.

- 1956. Fouilles et Travaux en Égypte 1954-1955. Orientalia 25: 251-68.

LÖNNQVIST, M. 2010. How to control nomads? A case study associated with Jebel Bishri in central Syria: West Semitic nomads in relation to the urban world, in L. Kogan, N. Koslova, S. Loesov \& S. Tischenko (ed.) City administration in the ancient Near East. Proceedings of the $53^{e}$ Rencontre Assyriologique Internationale volume 2: 115-39. Winona Lake (IN):

Eisenbrauns.

LYON, G.F. 1821. A narrative of travels in northern Africa in the years 1818-1819 and 1820. London: John Murray.

NIELSEN, N. 2016a. A corpus of Nineteenth Dynasty Egyptian pottery from Zawiyet Umm elRakham. Journal of Ancient Egyptian Interconnections 9: 59-71.

- 2016b. Subsistence strategies and craft production at the Ramesside fort of Zawiyet Umm el-Rakham. Unpublished PhD dissertation, University of Liverpool.

O'ConnOR, D. 1990. The nature of Tjemhu (Libyan) society in the later New Kingdom, in A. Leahy (ed.) Libya and Egypt: 1300-750 BC: 29-114. London: University of London.

Oriental Institute Epigraphic Survey. 1986. The battle reliefs of King Sety I. Chicago (IL): University of Chicago.

OsING, J. 1980. Libyen, Libyer, in W. Helck \& W. Westendorf (ed.) Lexicon der Ägyptologie, V.III: 1015-33. Wiesbaden: Harrassowitz.

PADGHAM, K. 2014. The scale and nature of the Late Bronze Age economies of Egypt and Cyprus. Oxford: Archaeopress.

Posener, G. 1940. Princes et pays d'Asie et de la Nubia, textes hieratiques sur des figurines d'envoutement du Moyen Empire. Brussels: Fondation Egyptologique Reine Elisabeth. 
RHODES, E.J. 2011. Optically stimulated luminescence dating of sediments over the past 200 000 years. Annual Review of Earth and Planetary Sciences 39: 461-88.

https://doi.org/10.1146/annurev-earth-040610-133425

RIEGER, A., T. VETTER \& H. MÖLLER. 2012. The desert dwellers of Marmarica, Western Desert: second millennium BCE to first millennium CE, in H. Barnard \& K. Duistermaat (ed.) The history of the peoples of the Eastern Desert: 157-73. Los Angeles (CA): University of California.

RITNER, R. 2009. Egypt and the vanishing Libyan: institutional responses to a nomadic people, in J. Szuchman (ed.) Nomads, tribes and the state in the ancient Near East: crossdisciplinary perspectives: 43-56. Chicago (IL): Oriental Institute of the University of Chicago.

Rosen, S.A. 2009. History does not repeat itself: cyclicity and particularism in nomadsedentary relations in the Negev in the long term, in J. Szuchman (ed.) Nomads, tribes and the state in the ancient Near East: cross-disciplinary perspectives: 57-86. Chicago (IL): Oriental Institute of the University of Chicago.

Rowe, A. 1953. A contribution to the archaeology of the Western Desert 1. Bulletin of the John Rylands Library 36: 128-45. https://doi.org/10.7227/BJRL.36.1.7

- 1954. A contribution to the archaeology of the Western Desert 2. Bulletin of the John Rylands Library 37: 484-500.

Rowton, M.B. 1973. Autonomy in a nomadic environment. Journal of Near Eastern Studies 32: 201-15. https://doi.org/10.1086/372237

SAGRILLO, T. 2012. Šîšaq's army: 2 chronicles 12: 2-3 from an Egyptological perspective, in G. Galil, A. Levinson-Gilbo'a, A.M. Maeir \& D. Kahn (ed.) The ancient Near East in the $12^{\text {th }}-10^{\text {th }}$ centuries BCE: culture and history. Proceedings of the international conference held at the University of Haifa, 2-5 May, 2010: 425-50. Münster: Ugarit-Verlag, SAMUEL, D. 1999. Bread making and social interactions at the Amarna workmen's village, Egypt. World Archaeology 31: 121-44.

- 2000. Brewing and baking, in P.T. Nicholson \& I. Shaw (ed.) Ancient Egyptian materials and technology: 537-76. Cambridge: Cambridge University Press.

SETHE, K. 1929. Ägyptische Texte zum Gebrauch im akademischen Unterricht: Texte der mittleren Reiches. Hildesheim: Georg Olms.

- 1933. Urkunden des Alten Reichs. Leipzig: Hinrichs.

- 1961. Urkunden der 18. Dynastie: Vierter Band. Berlin: Akademie-Verlag. 
SIMPSON, F. 2002. Evidence for a Late Bronze Age Libyan presence in the Egyptian fortress at Zawiyet Umm el-Rakham. Unpublished PhD Dissertation, University of Liverpool.

SNAPE, S. 1998. Walls, wells and wandering merchants: Egyptian control of Marmarica in the Late Bronze Age, in C.J. Eyre (ed.) Proceedings of the Seventh International Congress of Egyptologists, Cambridge, 3-9 September 1995: 1081-84. Leuven: Peeters.

- 2003. The emergence of Libya on the horizon of Egypt, in D.B. O'Connor \& S. Quirke (ed.) Mysterious lands: 93-106. London: UCL Press.

- 2004. The excavations of the Liverpool University mission to Zawiyet Umm el-Rakham 1994-2001. Annales du Service des antiquités de l'Egypte 78: 149-60.

- 2010. Vor der Kaserne: external supply and self-sufficiency at Zawiyet Umm el-Rakham, in M. Bietak, E. Czerny \& I. Forstner-Müller (ed.) Cities and urbanism in ancient Egypt: papers from a workshop in November 2006 at the Austrian Academy of Sciences: 271-88. Wien: Verlag der Österreichischen Akademie der Wissenschaften.

- 2013. A stroll along the Corniche: coastal routes between the Nile Delta and Cyrenaica in the Late Bronze Age, in F. Förster \& H. Riemer (ed.) Desert road archaeology in ancient Egypt and beyond: 439-54. Cologne: Heinrich-Barth-Institut.

SNAPE, S. \& G. GODENHO. In press. Zawiyet Umm el-Rakham II: the monuments of Nebre. Bolton: Rutherford.

SNAPE, S. \& P. WILSON. 2007. Zawiyet Umm el-Rakham I: the temple and chapels. Bolton: Rutherford.

SpALINGER, A.J. 1979. Some notes on the Libyans of the Old Kingdom and the later historical reflexes. Journal of the Society of the Study of Egyptian Antiquities 9: 125-60.

SPENCER, N. 2014. Amara West: considerations on urban life in colonial Kush, in D. Welsby \& J.R. Anderson (ed.) Proceedings of the $12^{\text {th }}$ international conference for Nubian studies, $1-$ 6 August 2012, London (British Museum Publications on Egypt and Sudan 1): 457-85. Leuven: Peeters.

- 2015. Creating a neighbourhood within a changing town: household and other agencies at Amara West, Nubia, in M. Mùller (ed.) Household studies in complex societies: (micro) archaeological and textual approaches: 169-210. Chicago (IL): Oriental Institute of the University of Chicago.

StRASSLER, R.B. (ed.). 2009. The landmark Herodotus: The Histories. New York: Anchor. SZUCHMAN, J. 2009. Integrating approaches to nomads, tribes and the state in the ancient Near East, in J. Szuchman (ed.) Nomads, tribes and the state in the ancient Near East: crossdisciplinary perspectives: 1-14. Chicago (IL): Oriental Institute of the University of Chicago. 
VetTer, T., A. Rieger \& A. NiCOlay. 2009. Ancient rainwater harvesting systems in the north-eastern Marmarica (northwestern Egypt). Libyan Studies 40: 9-23.

https://doi.org/10.1017/S0263718900004489

- 2014. Disconnected runoff contributing areas: evidence provided by ancient watershed management systems in arid north-eastern Marmarica (NW-Egypt). Geomorphology 212: 4157. https://doi.org/10.1016/j.geomorph.2013.10.002

VetTer, T., A. Rieger \& H. MÖller. 2013. Water, routes and rangelands: ancient traffic and grazing infrastructure in the eastern Marmarica (northwestern Egypt), in F. Förster \& H.

Riemer (ed.) Desert road archaeology in ancient Egypt and beyond: 455-84. Cologne:

Heinrich-Barth-Institut.

WHITE, D. 1999. Water, wood, dung and eggs: reciprocity in trade along the Late Bronze Age Marmarican coast, in P. Betancourt, V. Karageorghis, R. Laffineur \& W. Niemeier (ed.)

Meletemata: studies in Aegean archaeology presented to Malcolm H. Wiener as he enters his $65^{\text {th }}$ year: 931-36. Liège: University of Liège.

- 2002. Marsa Matruh II: the excavation. Philadelphia (PA): Institute for Aegean Prehistory. ZORN, J.R. 1994. Estimating the population size of ancient settlements: methods, problems, solutions, and a case study. Bulletin of the American Schools of Oriental Research 295: 3148. https://doi.org/10.2307/1357103

\section{Figure captions}

Figure 1. Map of the Marmarican coast west of Mersa Matrouh, showing the location of Zawiyet Umm el-Rakham and nearby remains of modern embanked fields at Wadi Magid and Wadi Umm el-Ashdan (map by N. Nielsen).

Figure 2. Plan of Zawiyet Umm el-Rakham showing the location of the areas under archaeological exploration (S. Snape).

Figure 3. View over the domestic structures in area K, looking south (photograph S. Thomas).

Figure 4. View of modern agriculture in wadis to the south of the site, looking south (photograph by S. Snape).

Figure 5. Examples of tools (a quern, handstone and sickle blades) for processing cereal products found in area $K$ (photograph by S. Snape \& N. Nielsen). 